\title{
Characterization of Four Viral Species Belonging to the Family Potyviridae Isolated from Ranunculus asiaticus
}

\author{
M. Turina, M. Ciuffo, R. Lenzi, L. Rostagno, L. Mela, E. Derin, and S. Palmano
}

First, second, third, fourth, and seventh authors: Istituto di Virologia Vegetale, CNR, Strada delle Cacce 73, 10135 Torino; and fifth and sixth authors: Istituto Regionale per la Floricoltura di Sanremo, Via Carducci 12, Sanremo. Accepted for publication 3 February 2006.

\begin{abstract}
Turina, M., Ciuffo, M., Lenzi, R., Rostagno, L., Mela, L., Derin, E., and Palmano, S. 2006. Characterization of four viral species belonging to the family Potyviridae isolated from Ranunculus asiaticus. Phytopathology 96:560-566.

Four different viral species were isolated from diseased Ranunculus asiaticus plants growing in Imperia Province (Italian Riviera-Liguria Region). Infected plants exhibited mosaic symptoms and growth abnormalities. The viruses were mechanically inoculated to a range of herbaceous hosts and differentiated biologically. Long flexuous particles were present in leaf dip extracts observed by electron microscopy. A general protocol for the amplification of potyvirus genome fragments through reverse transcription-polymerase chain reaction generated products

that were cloned and sequenced. Sequence and phylogenetic analysis suggested that three of these isolates could be considered new viral species belonging to the genus Potyvirus. The fourth isolate is a new member of the genus Macluravirus. Purified virus was used as antigen to produce a specific polyclonal antiserum in rabbit; serological features were established through double-antibody sandwich enzyme-linked immunosorbent assay (DAS-ELISA), antigen coated plate (ACP)-ELISA, and western blot analysis. DAS-ELISA was highly specific for each virus isolate, whereas some cross-reactivity was shown in ACP-ELISA and western blot analysis. Aphid transmission by Myzus persicae was demonstrated in a controlled environment for each of the four viral isolates, whereas no transmission through seed was observed.
\end{abstract}

Plant species belonging to the genus Ranunculus are commonly used as ornamental plants in a wide range of soil and climate conditions, particularly in the Mediterranean region, extending, in Europe, toward Great Britain. In North America, a few million bulbs of the 'Tecolote' (peony flowered) varieties are sold annually. The genus Ranunculus, originating in the Middle East, and the most common domesticated species, $R$. asiaticus L. (commonly known as Persian buttercups or Turban buttercups), were introduced in Europe in the 16th century A.D. (18). Most reproductive material (corms, tubers, and bulbs) is produced in Italy and France (4 to 5 million bulbs per year).

Numerous observations of possible viral symptoms in cultivated Ranunculus spp. motivated us to carry out an extensive survey of Ranunculus grown in the Imperia Province of the Italian Riviera, where Persian buttercup destined for the European market is propagated. Many viruses have been previously identified in Ranunculus spp., including members of the genera Tospovirus (Impatiens necrotic spot virus and Tomato spotted wilt virus) (31,35), Ophiovirus (Ranunculus white mottle virus) (32), Cucumovirus (Cucumber mosaic virus) (8), Necrovirus (Tobacco necrosis virus), and Tobravirus (Tobacco rattle virus) (22). Three potyviruses also have been recovered from Ranunculus spp.: Potato virus $Y$ (PVY) strain R (5), Turnip mosaic virus (TuMV) $(14,19)$, and Ranunculus mottle virus (RanMoV) $(9,15,16,22)$. Some of these viruses constitute a significant threat, others likely exist only occasionally in the crop without causing major losses.

In this work, we isolated and characterized four new viral species from commercial Persian buttercup varieties. We evaluated the ability of each virus isolate to cause symptoms in experi-

Corresponding author: M. Turina; E-mail address: m.turina@ivv.cnr.it

DOI: 10.1094/PHYTO-96-0560

(c) 2006 The American Phytopathological Society mentally inoculated plants. Based on host range and genomic and serological data, we propose that each viral isolate represents a new member of the family Potyviridae.

\section{MATERIALS AND METHODS}

Sample collection, prescreen, host range analysis, and electron microscopy. Plants expressing virus-associated symptoms were chosen during surveys in 2002 and 2003. To focus on potentially uncharacterized viruses, a preliminary screen was conducted by double-antibody sandwich enzyme-linked immunosorbent assay (DAS-ELISA) specific for TuMV and PVY (antisera from our collection) and for Cucumber mosaic virus according to protocols previously described (6). We identified plants that were negative for the above-mentioned potyviruses, but which were potyvirus-positive using wide spectrum monoclonal antibodies (potytest AS-0573/1 DSMZ, Braunschweig, Germany) or showed potyvirus-like particles by electron microscopy. The viruses were mechanically transmitted to a range of test plants as previously described (23). The viral isolates were maintained in Nicotiana benthamiana (Domin.) and/or $R$. sardous (Crantz) in a conditioned greenhouse where the temperature was maintained below $17^{\circ} \mathrm{C}$ (Persian buttercup is a late winter/early spring crop). Virions were observed in leaf dip extracts negatively stained with $2 \%$ uranyl acetate with an electron microscope (Philips CM10; Philips, Eidoven, the Netherlands).

Reverse transcription-polymerase chain reaction (RT-PCR) of infected plants, cloning of specific PCR products, and sequence analysis. Total RNA was prepared through phenolchloroform extractions and lithium chloride precipitation (28). Reverse transcription was carried out with the Omniscript Reverse Transcriptase (Invitrogen, Carlsbad, CA) according to the manufacturer's instruction using an oligo(dT) primer. PCR was carried out using $1 \mu \mathrm{l}$ of the RT reaction in a reaction mix containing 2 units of Taq polymerase (Polymed, Sambuca, Italy) following 
the protocol suggested by the manufacturer with some modification: $94^{\circ} \mathrm{C}$ for 4 min followed by 35 cycles of $94^{\circ} \mathrm{C}$ for $30 \mathrm{~s}, 50^{\circ} \mathrm{C}$ for $30 \mathrm{~s}$, and $72^{\circ} \mathrm{C}$ for $30 \mathrm{~s}$, and a final extension at $72^{\circ} \mathrm{C}$ for $10 \mathrm{~min}$. The oligonucleotides used as primer were a NotI-oligo(dT) anchored primer (5'-gggcggccgcttttttttttttttttttttv-3') and a degenerate oligonucleotide based on a conserved region of the coat protein (CP) gene (5'-tgaggatcctggtgyathgaraaygg- $\left.3^{\prime}\right)$. Selected PCR fragments were cloned in the pGEM-T easy vector (Promega, Madison, WI) and white colonies were screened by PCR using M13 forward and reverse primers. Plasmids with inserts of the appropriate size were purified (Qiagen, Hilden, Germany) and the inserts were sequenced using the dideoxy chain termination method (24).

To extend the sequence analysis to regions of the genome upstream of the potyvirus CP region, a second round of RT-PCR was carried out using one primer specific for each isolate (RN122, 5'ctgcgagatcagagaaa-3'; RN128, 5'-aaatcaaaagcataggg-3'; RN129, $5^{\prime}$-atcagtggtttgattgg-3'; and RN136, 5'-atggttttatcgggtag-3'), and a common primer based on the conserved region of the GDD motif within the nuclear inclusion $\mathrm{b}(\mathrm{NIb})$ protein $\left(5^{\prime}\right.$-ttygtnaayggngaygayyt-3') using reaction conditions described above but with an annealing temperature of $40^{\circ} \mathrm{C}$. The template for the RT-PCR was genomic viral RNA extracted as described (29). Template purity was further enhanced by recovering genomic RNA after electrophoresis in 1\% agarose using the RNAaid Kit (Bio101, Vista, CA). The RT-PCR products were cloned in pGEM-T and sequenced. Overlapping sequences were assembled for each virus isolate and open reading frame analysis was carried out on each sequence using the GCG software package (7). Predicted amino acid sequences were used for multiple alignment comparison with a series of 39 potyvirus sequences present in the GenBank, EMBL, DDBJ, and PDB databases using the CLUSTAL X software version 1.81 (27). Phylogenetic trees were calculated using the PROTPARS and PROTDIST together with the KITSCH software in the PHYLIP version 3.6 software package (10). Statistical significance was estimated by performing 100 replications of bootstrap resampling of the original alignment using SEQBOOT. A phylogenetic consensus tree was obtained using CONSENSE (majority rule consensus) from the same software package, and the resulting tree was displayed with DRAWGRAM. A database search for closely related viral species was carried out using BLAST (2).

Viral purification and antibody production. For each purification, $50 \mathrm{~g}$ of infected $N$. benthamiana or $R$. sardous was homogenized with $250 \mathrm{ml}$ of $0.5 \mathrm{M} \mathrm{K}_{2} \mathrm{HPO}_{4}$ with $20 \mathrm{mM} \mathrm{Na}_{2} \mathrm{SO}_{3}$, $10 \mathrm{mM}$ DIECA, and $5 \mathrm{mM}$ EDTA. After filtration through cheesecloth, the homogenate was centrifuged at $10,500 \times g$ for $10 \mathrm{~min}$. Triton $\mathrm{X}$ was added to the supernatant to a final concentration of $1 \%$, followed by stirring for $2 \mathrm{~h}$ at $4^{\circ} \mathrm{C}$ and then ultracentrifugation for $2 \mathrm{~h}$ at $235,000 \times g$ at $4^{\circ} \mathrm{C}$. Each pellet was resuspended overnight in $4 \mathrm{ml}$ of $0.05 \mathrm{M}$ Na-citrate buffer with $0.02 \mathrm{M} \mathrm{Na}_{2} \mathrm{SO}_{3}$, diluted to $25 \mathrm{ml}$ with the same buffer containing $1 \%$ Triton $\mathrm{X}$, and stirred for $1 \mathrm{~h}$ at $4^{\circ} \mathrm{C}$. After centrifugation $(16,000 \times g$ for $10 \mathrm{~min})$, the resulting supernatant was layered on a $20 \% \mathrm{Cs}_{2} \mathrm{SO}_{4}$ cushion and spun at $113,000 \times g$ for $180 \mathrm{~min}$. The final pellet was resuspended in $0.5 \mathrm{ml}$ of $0.01 \mathrm{M} \mathrm{K}$-phosphate buffer, pH 7.0. Purity of the viral suspension was evaluated by electron microscopy and through Coomassie brilliant blue staining of proteins separated through a $10 \%$ tris-tricine PAGE (25). Protein quantification utilized the Quick StartTM Bradford Dye Reagent (Bio-Rad, Hercules, CA).

New Zealand rabbits were injected with $1 \mathrm{mg}$ of purified virus emulsified with Freund's complete adjuvant. Booster injections were repeated every 2 weeks up to five injections. Rabbit serum was collected through two or three bleedings beginning 30 days after the first injection at 2-week intervals.

ELISA and western blot analysis. Antisera were crossabsorbed with healthy plant extracts and the immunoglobulin $\mathrm{G}$
(IgG) fractions were subjected to affinity chromatography on protein G columns (Pharmacia, Skolie, IL) as suggested by the manufacturer. Purified IgG was used for antigen coated plate (ACP)-ELISA and western blot analysis. Aliquots of IgG derived from different antisera were conjugated to alkaline phosphatase as previously described (6) and used for DAS-ELISA. DAS- and ACP-ELISA were carried out as previously described, with preliminary trials to establish optimal antibody dilutions $(13,23)$. Total leaf protein extracts, sodium dodecyl sulfate-polyacrylamide gel electrophoresis (SDS-PAGE), and western blot analysis were carried out as detailed (28).

Seed and aphid transmission. Aphid transmission experiments were carried out following standard protocols for nonpersistent transmission. Two Myzus persicae Sulzer individuals reared on healthy pepper plants were starved for 2 to $3 \mathrm{~h}$ and then transferred to a symptomatic leaf of an $R$. sardous plant that tested positive by DAS-ELISA for a single infection with one of the four viruses. After observing at least two test probes, the aphids were transferred to $R$. asiaticus plants (five aphid individuals for each plant), which were obtained from seed, and which had tested negative by DAS-ELISA for each of the four viral isolates. The plants where then treated with Pirimicarb $5 \mathrm{~h}$ after aphid transfer, and maintained in an insect-proof greenhouse for symptom monitoring. Each test plant was evaluated for virus infection by DAS-ELISA for the virus under examination. For each virus, at least three $R$. asiaticus plants were used for each experiment, and the experiment was repeated twice. In the case of one isolate, the experiment was repeated twice more using infected $N$. benthamiana as source plants.

Seed transmission experiments were carried out for each of the four virus isolates in two different plant hosts: $R$. asiaticus and $R$. sardous. Seeds were collected from mechanically inoculated plants that tested positive by DAS-ELISA for single infection with each of the four viruses and which were manually pollinated with pollen collected from infected plants. Five seeds per pot were planted and DAS-ELISA was performed for each of the viruses 3 months after planting.

Survey of Ranunculus crops through ELISA tests. During the growing seasons 2003 to 2004, a limited number of farms particularly specialized in $R$. asiaticus growth and propagation were surveyed. Symptomatic leaves were collected and tested by DAS-ELISA for each of the four virus isolates.

\section{RESULTS}

Virus isolation, symptomatology, and host range. After the prescreen with DAS-ELISA for PVY and TuMV, a number of samples were positive for potyvirus infection using the generic potyvirus monoclonal antibody or by electron microscopy. We mechanically inoculated a number of host plants with some of these isolates. We identified four different viral isolates, which we provisionally named RN122, RN128, RN129, and RN136 during 2 years of survey $(2002,2003)$ in various locations of the Imperia Province (Italian Riviera). Each isolate was back-inoculated on $R$. asiaticus and $R$. sardous, and symptoms were observed (Fig. $1)$. In particular, $R$. sardous exhibited very reproducible leaf symptoms (Fig. 1A), which varied in degree of severity among the four isolates.

The results of a more detailed host range analyses are shown in Table 1. Three of the four isolates have at least one local lesion host, whereas all four isolates have at least one systemic host. For the three isolates that caused local lesions on Chenopodium amaranticolor Coste et Reyn, three serial passages through a single lesion were carried out to ensure, when possible, clonality of the isolates. To address Koch's postulates, each viral isolate was mechanically inoculated onto $R$. asiaticus after purification on a cesium sulfate gradient, and after single lesions serial passages when possible. Mosaic and occasional flower breaking symptoms 
varying in severity among the four viral isolates were reproduced. Each isolate had a distinct host range, which was narrow for RN129, RN128, and RN136, and broader for RN122. For each plant species tested, systemic infection was assayed by specific
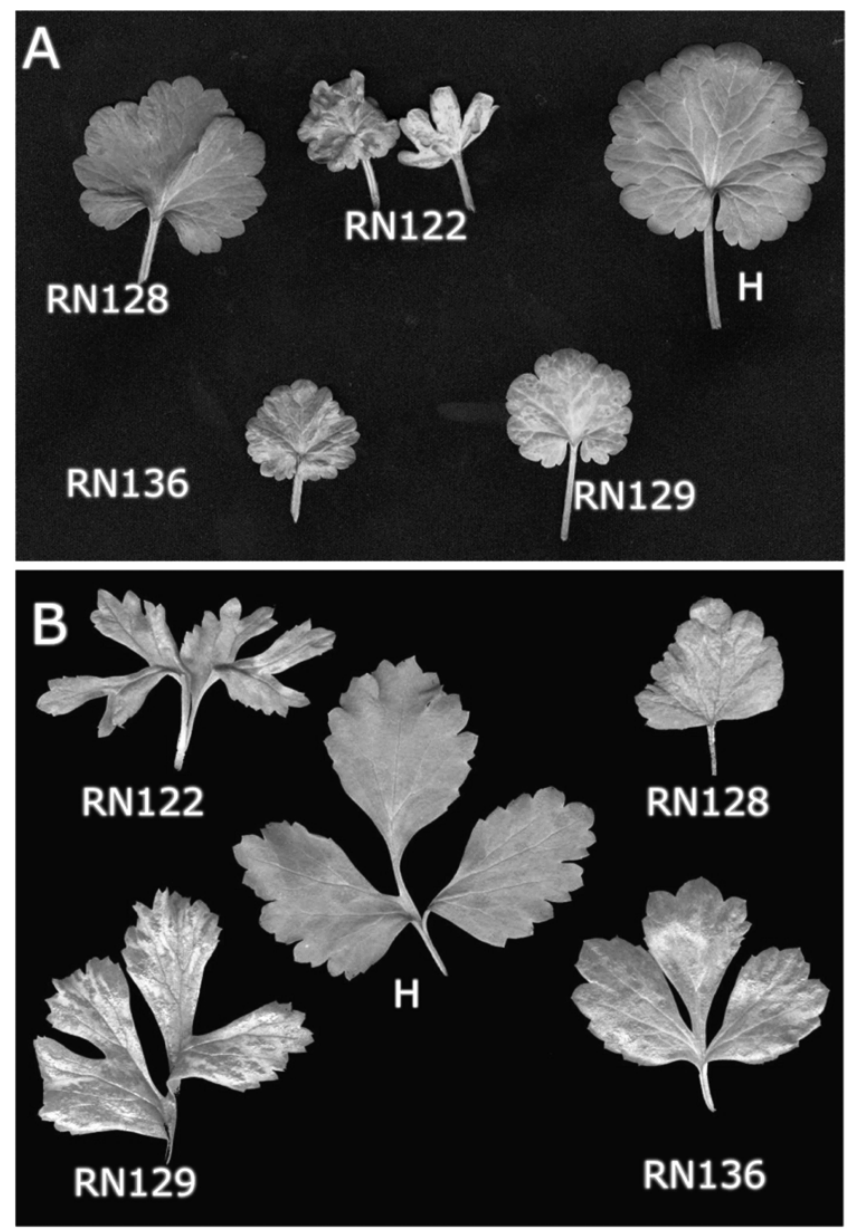

Fig. 1. Symptoms induced by the four viral isolates were characterized 15 days post mechanical inoculation on $\mathbf{A}$, Ranunculus sardous and $\mathbf{B}, R$. asiaticus.
DAS-ELISA to identify potential symptomless infections. The four viral isolates also were observed by electron microscopy, and each showed elongated flexuous particles with features typical of potyviruses.

Molecular characterization and phylogenetic placement. For each of the four viral isolates, a 650- to 700-bp product, corresponding to the $3^{\prime}$ end of the viral genomes, was obtained by RT-PCR using generic primers for potyviruses. Restriction fragment length polymorphism analysis with the restriction enzymes EcoICRI and HpaI was carried out in order to ensure a homogeneous RT-PCR product for isolate RN136, which was the only isolate that could not be serially transmitted through single lesions (data not shown). After cloning and sequencing of the initial RT-PCR products, we amplified an upstream $\approx 1-\mathrm{kb}$ segment of the viral genome corresponding to the NIb coding region and the $5^{\prime}$ proximal coding region of the CP. For each virus isolate, a sequence including the entire $\mathrm{CP}$ coding region and the $3^{\prime}$ proximal coding region of $\mathrm{NIb}$ was obtained. The four viral sequences were deposited in GenBank and given the following accession numbers: DQ152190 (RN122), DQ152193 (RN128), DQ152191 (RN129), and DQ152192 (RN136). From BLAST searches of the various databases with the four sequences, we retrieved the highest matching scores with members of the genus Potyvirus for isolates RN122, RN129, and RN136, whereas RN128 showed greater similarity to members of the genus Macluravirus. The putative proteinase cleavage site between NIb and $\mathrm{CP}$ was determined for the three putative potyviruses by alignment of our isolates with related potyviruses sequences. The same cleavage site also was predicted for the putative macluravirus; although we note that the $\mathrm{NIb} / \mathrm{CP}$ cleavage site has not been experimentally determined for any of the viruses used in the alignment.

The phylogenetic analysis carried out using the $\mathrm{NIb}-\mathrm{CP}$ region of the four Ranunculus isolates and 39 other viruses are shown in Figure 2. RN128 is included in the Macluravirus cluster, whereas RN129 was associated in a cluster with the potyviruses Carrot thin leaf virus (CTLV) and Zantedeschia mosaic virus (ZaMV). Isolates RN122 and RN136 were not closely related to other potyviruses but shared with other potyviruses a node consisting of a polytomy.

Based on pairwise alignment, we also calculated the percent amino acid identity of the $\mathrm{CP}$. In Table 2 , we show the values

TABLE 1. Presence of virus and symptoms on plant species inoculated with four viruses isolated from Ranunculus spp. (RN122, RN128, RN129, and RN136)

\begin{tabular}{|c|c|c|c|c|c|c|c|c|c|c|c|c|c|}
\hline \multirow[b]{2}{*}{ Family } & \multirow[b]{2}{*}{ Species $^{\mathrm{a}}$} & \multicolumn{4}{|c|}{ Symptoms on inoculated leaves ${ }^{b}$} & \multicolumn{4}{|c|}{ Systemic symptoms ${ }^{b}$} & \multicolumn{4}{|c|}{ ELISA on uninoculated leaves ${ }^{c}$} \\
\hline & & RN129 & RN128 & RN122 & RN136 & RN129 & RN128 & RN122 & RN136 & RN129 & RN128 & RN122 & RN136 \\
\hline Amaranthaceae & Gomphrena globosa & 0 & 0 & nll & 0 & 0 & 0 & 0 & 0 & - & - & - & - \\
\hline \multirow[t]{3}{*}{ Chenopodiaceae } & Chenopodium amaranticolor & cll & cll & cll & 0 & 0 & 0 & 0 & 0 & - & - & - & - \\
\hline & Chenopodium quinoa & 0 & nll & cll & 0 & 0 & 0 & 0 & 0 & + & - & + & - \\
\hline & Spinacea oleracea & 0 & 0 & 0 & 0 & 0 & 0 & 0 & 0 & - & + & + & - \\
\hline Cucurbitaceae & Cuсurbita реро & 0 & nll & cll & 0 & 0 & 0 & 0 & 0 & - & - & - & - \\
\hline Labiatae & Ocimum basilicum & 0 & n.rs & 0 & 0 & 0 & 0 & 0 & 0 & - & - & - & - \\
\hline \multirow[t]{7}{*}{ Solanaceae } & Datura starmonium & 0 & 0 & cll & 0 & 0 & 0 & $\mathrm{f}$ & 0 & - & - & + & - \\
\hline & Nicotiana benthamiana & 0 & cll & 0 & 0 & 0 & $\mathrm{~m}, \mathrm{~d}$ & $\mathrm{~m}, \mathrm{~d}$ & 0 & - & + & + & - \\
\hline & Nicotiana clevelandii & 0 & 0 & 0 & 0 & 0 & 0 & $\mathrm{~m}, \mathrm{~d}$ & 0 & - & - & + & + \\
\hline & Nicotiana megalosiphon & 0 & 0 & 0 & 0 & 0 & 0 & $\mathrm{~m}, \mathrm{~d}$ & 0 & - & - & + & + \\
\hline & $\begin{array}{l}\text { Nicotiana rustica } \\
\text { Nicotiana tabacum }\end{array}$ & 0 & 0 & 0 & 0 & 0 & 0 & $\mathrm{~m}, \mathrm{~d}$ & 0 & - & - & + & - \\
\hline & White Burley & 0 & cll & cll & 0 & 0 & 0 & 0 & 0 & - & - & - & + \\
\hline & Petunia X hybrida & 0 & 0 & 0 & 0 & 0 & 0 & 0 & 0 & - & - & + & - \\
\hline \multirow[t]{2}{*}{ Ranuncolaceae } & Ranunculus sardous & $\mathrm{m}$ & nll & $\mathrm{mm}$ & nll & $\mathrm{m}$ & $\mathrm{mm}$ & $\mathrm{m}, \mathrm{d}$ & $\mathrm{m}$ & + & + & + & + \\
\hline & Ranunculus asiaticus & $\mathrm{mm}$ & $\mathrm{mm}$ & $\mathrm{mm}$ & $\mathrm{mm}$ & $\mathrm{m}$ & $\mathrm{m}, \mathrm{d}$ & $\mathrm{m}, \mathrm{d}$ & $\mathrm{m}$ & + & + & + & + \\
\hline Fabaceae & Faseolus vulgaris cv. Saxa & py & 0 & 0 & 0 & 0 & 0 & m.cl & 0 & - & - & + & - \\
\hline
\end{tabular}

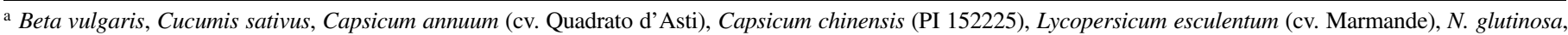
and Vinca rosea did not show any local or systemic symptom, and did not react in double-antibody sandwich enzyme-linked immunosorbent assay (DASELISA) for any of the four viruses inoculated.

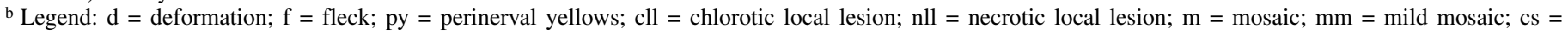
chlorotic spot; n.rs $=$ necrotic ring spot; and $0=$ no symptoms observed.

${ }^{c}+$ and - symbols correspond to infected/healthy ratio $(\mathrm{I} / \mathrm{H})$ of absorbance values, respectively, over or below 3 in DAS-ELISA tests. 
obtained for the comparisons among our isolates and the most closely related viruses, based on BLAST search results.

Purification, antibody production, and assessment of serological diagnostic tools. After purification of each isolate, the $\mathrm{CP}$

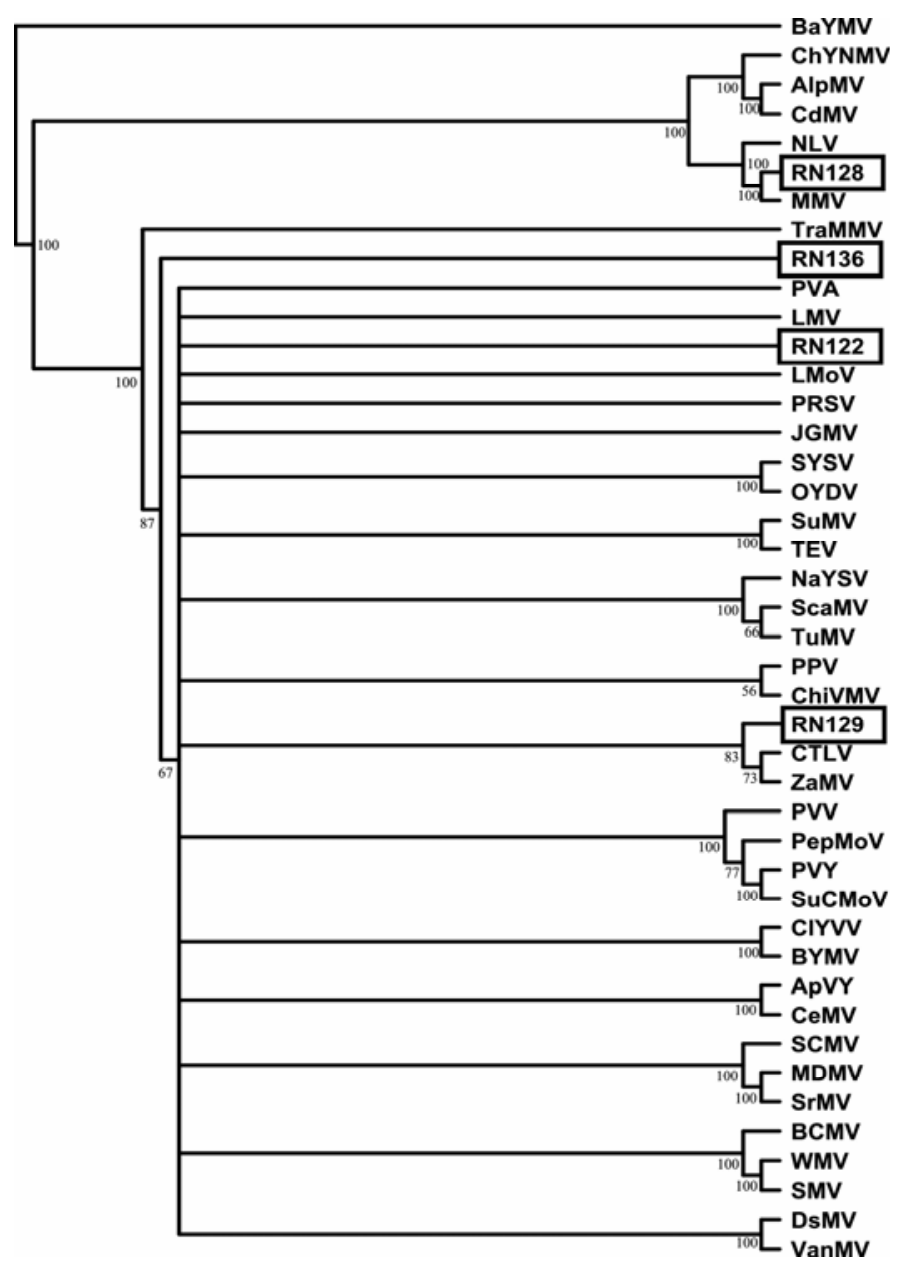

Fig. 2. Consensus phylogenetic tree obtained from alignments of nuclear inclusion b-coat protein sequences of 43 viruses belonging to the family Potyviridae with bootstrap analysis values at the nodes (only those $>70$ are shown). Branches at nodes with a bootstrap value $<50$ have been collapsed to polytomy. The phylogenetic analysis was carried out with PROTDIST and KITSCH software (PHYLIP software package). Barley yellow mosaic virus (BaYMV) (NP_148999.1) was used as outgroup. All the accession numbers of the viral sequences with their names and acronym used in the figure are specified as follows: Alpinia mosaic virus (AlpMV) AAP30734, Apium virus $Y$ (ApVY) AAF80961, Bean common mosaic virus (BCMV) NP_570723.1, Bean yellow mosaic virus (BYMV) NP_612218.1, Carrot thin leaf virus (CTLV) AAF80962, Cardamom mosaic virus (CdMV) AAX31144, Celery mosaic virus (CeMV) AAF80967, Chili veinal mottle virus (ChiVMV) BAA25793, Chinese yam necrotic mosaic virus (ChYNMV) BAB62224, Clover yellow vein virus (ClYVV) AAB21048.2, Dasheen mosaic virus (DsMV) CAC83052, Johnsongrass mosaic virus (JGMV) CAA81549, Lettuce mosaic virus (LMV) NP_619667, Lily mottle virus (LMoV) BAB83080, Maclura mosaic virus (MacMV) AAB02823, Maize dwarf mosaic virus (MDMV) CAA04929, Narcissus latent virus (NLV) AAB02824, Narcissus yellow stripe virus (NYSV) AJ311372, Onion yellow dwarf virus (OYDV) AJ409313, Papaya ring spot virus (PRSV) CAA47905, Pepper mottle virus (PepMoV) NP041276, Plum pox virus (PPV) AAB05823, Potato virus A (PVA) AAB24779, Potato virus $Y$ (PVY) NTN AAN87843, Potato virus $V$ (PVV) AAS01051, Scallion mosaic virus (ScaMV) NP_570725, Shallot yellow stripe virus (SYSV) AJ488151, Sorghum mosaic virus (SrMV) CAC84438, Soybean mosaic virus (SMV) NP_072165, Sugarcane mosaic virus (SCMV) AAS76887, Sunflower chlorotic mottle virus (SuCMoV) AAQ21400, Sunflower mosaic virus (SuMV) AAL73971, Tradescantia mild mosaic virus (TraMMV) AAW38932, Tobacco etch virus (TEV) AAA98576, Turnip mosaic virus (TuMV) BAC79395, Vanilla mosaic virus (VanMV) CAE83574, Watermelon mosaic virus (WMV) AAX89506, and Zantedeschia mosaic virus (ZaMV) CAF32247. molecular mass was estimated through Coomassie brilliant blue staining of protein samples separated through PAGE. Each virus yielded a single discrete polypeptide of apparent different molecular weight. The estimated $\mathrm{CP}$ molecular weight ranged between 30,000 and 50,000 (Fig. 3). Purified IgGs were initially used for ACP-ELISA. The antigens, diluted 1:100, were tested against RN122, RN128, RN129, and RN136 antisera. The absorbance value was determined after 30' (Table 3 ). We observed a cross-reaction between isolates RN122 and RN129 and between RN122 and TuMV using antisera against RN122 and RN129; a weak cross-reaction was noted between RN136 and TuMV using antiserum against RN136. Antisera conjugated with alkaline phosphatase were used for DAS-ELISA. Leaf sap from infected plants (diluted 1/20) was tested against the four conjugated antisera and no cross-reaction was observed (Table 4).

A western blot analysis was carried out using total soluble proteins extracted from leaves infected with the four isolates. This diagnostic tool allows estimation of the molecular mass of $\mathrm{CP}$ and the possible cross-reactions between isolates under denaturing conditions. We observed the cross-reaction between RN122 and RN129 using an anti-RN122 antiserum and a weak serological relationship between RN122 and RN136, but only after film overexposure (Fig. 4).

Seed and aphid transmission and field survey results. The results of seed transmission tests were all negative, whether $R$. asiaticus or $R$. sardous was the host plant (more than 600 seedlings were tested for each virus).

Four different aphid transmission tests were conducted. From the first and second tests, using $R$. asiaticus as host and as source of inoculum, we obtained positive results for all the viral isolates except RN128. A third test was carried out only for RN128 employing six $N$. benthamiana plants. Two tested plants were positive after being in contact with aphids previously exposed to infected $N$. benthamiana. The fourth test confirmed the results of the third, with the inclusion of $R$. sardous and $R$. asiaticus as plant hosts for the experiment (Table 5).

From the surveys carried out in 2003 to 2004 (Table 6), it was evident that RN122 and RN129 are the more widespread viruses, and often present in mixed infections. RN128 and RN136 were found in one farm each.

\section{DISCUSSION}

Presence of potyviruses on ornamental Ranunculus species has been documented since the early 1950s (21). In the mid-1960s, RanMoV was shown to infect $R$. asiaticus in the United States (15). In the early 1970s, a potyvirus isolated from Ranunculus in India was partially characterized (20). Ranunculus virus, a poty-

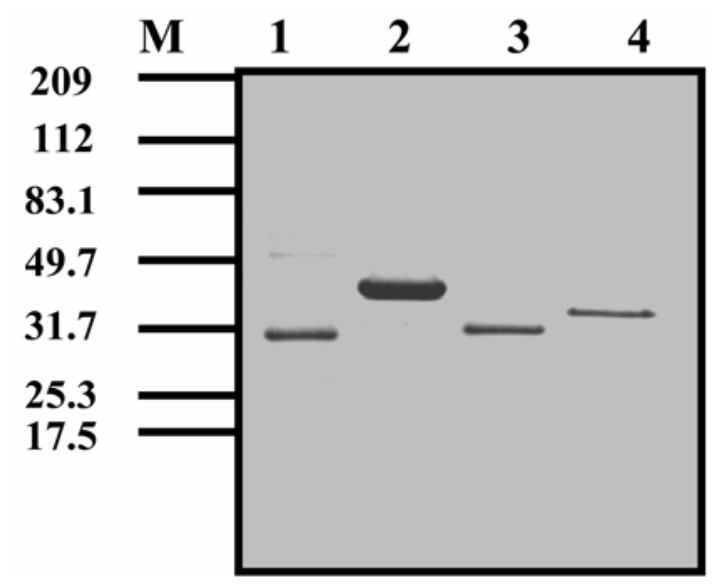

Fig. 3. Polyacrylamide gel electrophoresis gel of coat proteins of purified viruses. M, molecular weight marker; lane 1, RN122; lane 2, RN128; lane 3, RN129; and lane 4, RN136. 
virus isolated in Southern California in the late 1980s, was shown to be an isolate of RanMoV (9). No sequence data are available for any of the above-mentioned isolates, but based on host range, we ascertained that the four viral isolates are not identical to the partially characterized RanMoV, as isolates RN122 and RN128 can readily infect $N$. benthamiana systemically; RN129 can infect Phaseolus vulgaris systemically, and RN136 can infect $N$. tabacum. Given these host range differences, we cannot rule out that one of the viruses we characterized is indeed a strain of RanMoV. In Italy, a potyvirus repeatedly isolated since 1983 was partially characterized as a Ranunculus isolate of PVY (5). However, none of the four isolates reacted with PVY antiserum and the sequence comparisons do not indicate a relationship with the PVY subgroup of potyviruses (1).

Purified virus of each of the four viral isolates produced mosaic and flower breaking symptoms on $R$. asiaticus. For the three isolates that had a local lesion host, we executed three successive rounds of single lesion isolation and reinoculation before viral purification. Moreover, mobility of $\mathrm{CP}$ in a Coomassie brilliant blue-stained SDS-PAGE gel was different for each purified viral isolate. Collectively, these data fulfill Koch's postulates for each of the four viral isolates.

A recent comprehensive work on phylogenetic placement of the viruses belonging to the family Potyviridae (1) confirmed previous work by Shukla and Ward (26), which used CP percentage of identity (or similarity) at the amino acid level to distinguish different viral species within the genus Potyvirus. In our study, the $\mathrm{CP}$ of each new isolate differs from that of its nearest known relative sufficiently to be discriminated as new viral species. Moreover, RN128 has a percent identity below the threshold for viruses belonging to the genus Potyvirus. Data based on CP percentage of identity are supported by the phylogenetic analysis showing, with high degree of robustness, that RN128 is a new member of the genus Macluravirus within the family Potyviridae. The viral isolates RN122 and RN136 did not associate, with any statistical significance, with any of the potyvirus subgroupings present in the genus Potyvirus and previously identified $(1,34)$. Isolate RN129 was associated with CTLV and ZaMV with some statistical significance when using both the parsimony and distances methods to evaluate phylogenetic relationships among the various potyviruses included in the comparison, but such association was not confirmed when only $\mathrm{CP}$ alignment data were used.

Based on the various biological and molecular data gathered, we suggest that each of the four viral isolates is representative of a new viral species. Based on differential symptoms on $R$. sardous (this species was chosen because the symptoms were clearly differentiated and reproducible), we suggest the following names: RN122 would be named Ranunculus leaf distortion virus, RN128 would be called Ranunculus latent virus, RN129 designated as

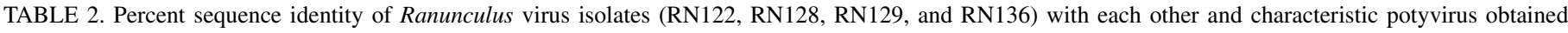
from alignments of coat protein sequences ${ }^{\mathrm{a}}$

\begin{tabular}{|c|c|c|c|c|c|c|c|c|c|c|c|c|c|}
\hline & RN122 & RN128 & RN129 & RN136 & TuMV & ClYVV & JYMV & CTLV & NYSV & TEV & ApVY & MacMV & NLV \\
\hline RN122 & 100 & 27 & 63 & 54 & 61 & 61 & 62 & 62 & 59 & 63 & 59 & 25 & 26 \\
\hline RN128 & $\ldots$ & 100 & 27 & 23 & 26 & 28 & 27 & 26 & 26 & 27 & 25 & 54 & 56 \\
\hline RN129 & $\ldots$ & $\ldots$ & 100 & 58 & 65 & 57 & 68 & 71 & 66 & 63 & 58 & 24 & 27 \\
\hline RN136 & $\ldots$ & $\ldots$ & $\ldots$ & 100 & 57 & 54 & 56 & 56 & 57 & 60 & 55 & 22 & 25 \\
\hline
\end{tabular}

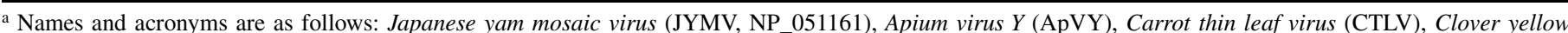
vein virus (ClYVV), Turnip mosaic virus (TuMV), Narcissus latent virus (NLV), Narcissus yellow stripe virus (NYSV), Maclura mosaic virus (MacMV), and Tobacco etch virus (TEV).

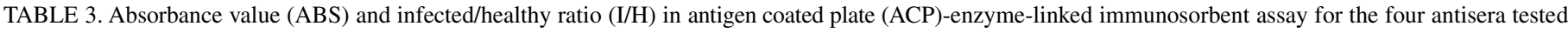
against infected plant extracts diluted $1 / 100^{\mathrm{a}}$

\begin{tabular}{|c|c|c|c|c|c|c|c|c|}
\hline \multirow[b]{2}{*}{ Antigens $1 / 1,000$} & \multicolumn{2}{|c|}{ Antiserum RN122 } & \multicolumn{2}{|c|}{ Antiserum RN128 } & \multicolumn{2}{|c|}{ Antiserum RN129 } & \multicolumn{2}{|c|}{ Antiserum RN136 } \\
\hline & ABS & $\mathrm{I} / \mathrm{H}$ & ABS & $\mathrm{I} / \mathrm{H}$ & ABS & $\mathrm{I} / \mathrm{H}$ & ABS & $\mathrm{I} / \mathrm{H}$ \\
\hline RN122 & 2.18 & 28.1 & 0.06 & 1.1 & 0.29 & 3.5 & 0.13 & 1.2 \\
\hline RN128 & 0.11 & 1.4 & 1.63 & 27.9 & 0.08 & 1.0 & 0.28 & 2.6 \\
\hline RN129 & 0.64 & 8.3 & 0.06 & 1.0 & 1.85 & 22.8 & 0.11 & 1.0 \\
\hline RN136 & 0.11 & 1.4 & 0.09 & 1.5 & 0.13 & 1.6 & 2.61 & 24.7 \\
\hline Clover yellow vein virus & 0.12 & 1.6 & 0.06 & 1.0 & 0.08 & 1.0 & 0.13 & 1.2 \\
\hline Turnip mosaic virus & 0.26 & 3.4 & 0.07 & 1.2 & 0.98 & 12.1 & 0.34 & 3.3 \\
\hline Healthy Ranunculus spp. & 0.08 & 1.0 & 0.06 & 1.0 & 0.08 & 1.0 & 0.11 & 1.0 \\
\hline Healthy Nicotiana benthamiana & 0.11 & 1.5 & 0.08 & 1.3 & 0.06 & 0.8 & 0.14 & 1.3 \\
\hline
\end{tabular}

a The values of $\mathrm{I} / \mathrm{H}$ higher than 3 are indicated by bold.

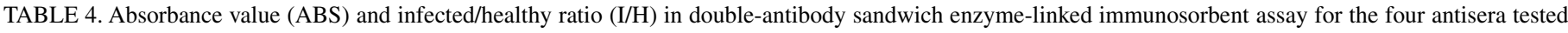
against infected plant extracts diluted $1 / 20^{\mathrm{a}}$

\begin{tabular}{|c|c|c|c|c|c|c|c|c|}
\hline \multirow[b]{2}{*}{ Antigens $1 / 20$} & \multicolumn{2}{|c|}{ Antiserum RN122 } & \multicolumn{2}{|c|}{ Antiserum RN128 } & \multicolumn{2}{|c|}{ Antiserum RN129 } & \multicolumn{2}{|c|}{ Antiserum RN136 } \\
\hline & ABS & $\mathrm{I} / \mathrm{H}$ & ABS & $\mathrm{I} / \mathrm{H}$ & ABS & $\mathrm{I} / \mathrm{H}$ & ABS & $\mathrm{I} / \mathrm{H}$ \\
\hline RN122 & 2.08 & 30.5 & 0.07 & 1.2 & 0.06 & 1.1 & 0.05 & 1.0 \\
\hline RN128 & 0.14 & 2.0 & 1.42 & 26.1 & 0.06 & 1.1 & 0.05 & 1.0 \\
\hline RN129 & 0.15 & 2.2 & 0.07 & 1.3 & 2.40 & 45.7 & 0.05 & 1.0 \\
\hline RN136 & 0.09 & 1.4 & 0.06 & 1.1 & 0.06 & 1.2 & 1.84 & 35.0 \\
\hline Healthy Ranunculus spp. & 0.07 & 1.0 & 0.05 & 1.0 & 0.05 & 1.0 & 0.05 & 1.0 \\
\hline Turnip mosaic virus & 0.07 & 1.1 & 0.05 & 1.0 & 0.05 & 1.0 & 0.05 & 1.0 \\
\hline Healthy Nicotiana benthamiana & 0.09 & 1.3 & 0.06 & 1.0 & 0.06 & 1.1 & 0.06 & 1.1 \\
\hline Clover yellow vein virus & 0.06 & 0.9 & 0.06 & 1.0 & 0.06 & 1.1 & 0.06 & 1.1 \\
\hline
\end{tabular}

a The values of $\mathrm{I} / \mathrm{H}$ higher than 3 are indicated by bold. 
Ranunculus mild mosaic virus, and RN136 referred to as Ranunculus mosaic virus (compare Fig. 1).

For each of the viruses sequenced, we analyzed the derived molecular features, and could identify all the expected motifs. In particular, given the putative NIb-CP proteolytic site, we could align the putative aphid transmission motifs in the three isolates belonging to the genus Potyvirus: only RN136 has the typical DAG motif, whereas RN122 and RN129 have the NAG motif, which was previously shown to be active in Bean yellow mosaic virus and Tobacco vein mottling virus $(3,36)$. The overall derived MW of the CP is in general agreement with the electrophoretic mobility in SDS-PAGE, and with the various MW of potyvirus CP (30). The aphid transmission experiment carried out in a controlled environment is consistent with a nonpersistent transmission mode. The difficulties observed with the isolate RN128 could be the result of a different transmission mode, particularly

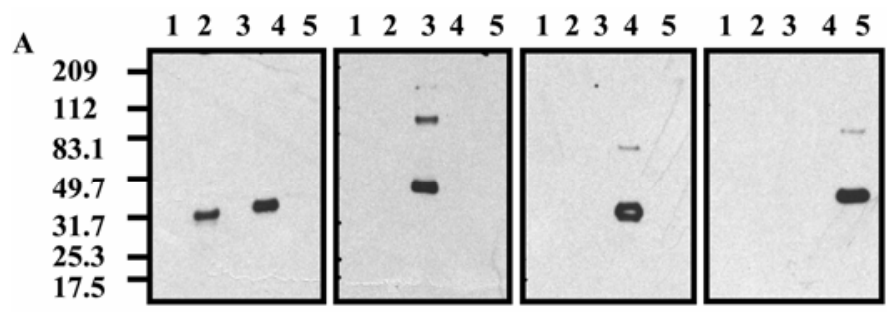

B
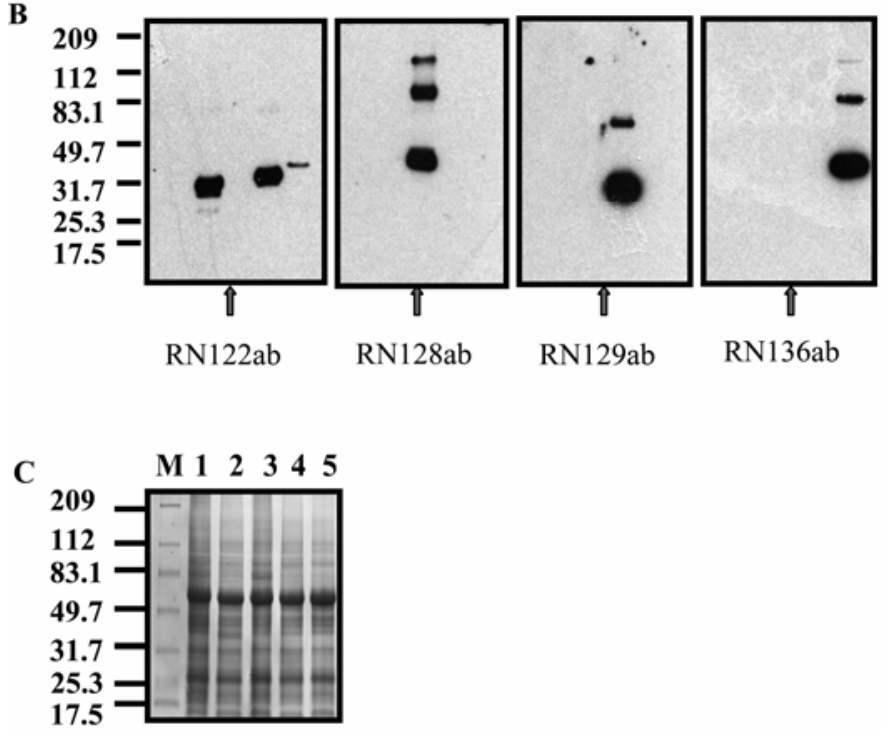

Fig. 4. Western blot analysis (enhanced chemiluminescence detection method) of whole leaf protein extracts separated in 12\% tris-tricine gels. Lane 1, healthy sample; lane 2, RN122; lane 3, RN128; lane 4, RN129; and lane 5, RN136. Each set of samples was probed with the four polyclonal antisera (RN122ab, RN128ab, RN129ab, and RN136ab) at a dilution of 1:2,000. Secondary antibodies were diluted 1:6,000. The films were developed after $\mathbf{A}$, 10-s exposure and $\mathbf{B}, 10$-min exposure. $\mathbf{C}$ indicates Coomassie staining for an estimate of concentration of total protein extracts. Molecular weight standards are indicated to the left of the panel. taking into account the lack of a DAG or NAG motif in the putative CP amino acid sequence. Moreover, aphid transmission in Alpinia mosaic virus was shown to be aphid specific (17), and our lack of success could be explained by high virus-vector specificity not taken into account in our experiment. Chinese yam necrotic mosaic virus also was shown to be aphid transmitted (11) as well as the other three macluraviruses, where in some instances vector specificity was not strict $(4,12)$.

The putative cleavage site for the three potyviruses are Q/S, Q/A, and Q/G for RN122, RN129, and RN136, respectively. A putative NIa cleavage site also was suggested for macluraviruses (4); alignment of the NIb-CP region sequenced suggests such putative cleavage site (LQ/M) is conserved also in RN128. The CP derived molecular weight is below the expected molecular weight (compared with the observed electrophoretic mobility). Such discrepancy has been observed for all macluraviruses so far characterized. In the case of RN128, such anomalous running pattern could be due to the unusually high pI (10.2) compared with the other $\mathrm{CP}$ for both potyviruses and macluraviruses.

The data from the surveys carried out in 2003 and 2004 were insufficient to generalize a differentiated prevalence pattern for each viral isolate, but support the idea that each virus causes disease of ornamental Persian buttercup in this area. This is particularly true for two of the viral isolates, RN122 and RN129, which were repeatedly found in different areas and in different years. As for the severity and importance of each viral species, we need to bear in mind that potyviruses were shown to be involved in synergistic interactions with other viruses (33), and since viruses from other taxonomic groups were shown to be present in Ranunculus spp., mixed infection could raise the overall danger for Persian buttercup crops.

\section{ACKNOWLEDGMENTS}

We thank C. Perrone for skillful technical assistance in the laboratory and greenhouse, and D. Grubb for editing the manuscript. This work was financed in part through a collaboration with the "Istituto Regionale per la Floricoltura di Sanremo."

TABLE 6. Number of infected plants of Ranunculus samples collected during surveys of farms in Liguria region tested by double-antibody sandwich enzyme-linked immunosorbent assay

\begin{tabular}{lccccc}
\hline & \multicolumn{5}{c}{ 2003-2004 surveys } \\
\cline { 2 - 6 } Location & $\begin{array}{c}\text { No. of } \\
\text { plants tested }\end{array}$ & RN122 & RN128 & RN129 & RN136 \\
\hline Poggio Sanremo & 23 & 13 & 0 & 15 & NT \\
Bastera & 11 & 11 & 1 & 10 & NT \\
Arma di Taggia & 16 & 7 & 0 & 8 & NT \\
Coldirodi & 30 & 24 & 0 & 22 & 1 \\
S.Lorenzo al Mare & 1 & 1 & 0 & 0 & 0 \\
Riva Ligure & 1 & 1 & 0 & 0 & 0 \\
Cipressa & 2 & 0 & 2 & 0 & 0 \\
Imperia & 1 & 0 & 0 & 1 & 0 \\
Camporosso & 1 & 0 & 0 & 1 & 0 \\
\hline
\end{tabular}

${ }^{\text {a }} \mathrm{NT}=$ not tested.

TABLE 5. Aphid transmission tests, number of infected plants after aphid transmission experiment ${ }^{\mathrm{a}}$

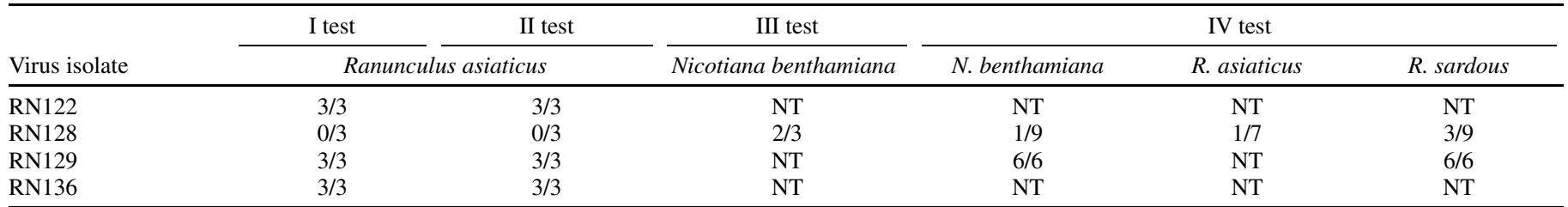

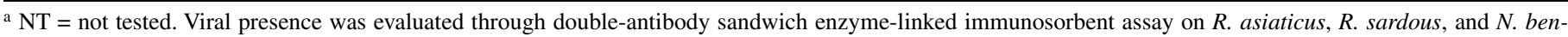
thamiana plants. 


\section{LITERATURE CITED}

1. Adams, M. J., Antoniw, J. F., and Faquet, C. M. 2005. Molecular criteria for genus and species discrimination within the family Potyviridae. Arch. Virol. 150:459-479.

2. Altschul, S. F., Gish, W., Miller, W., Myers, E. W., and Lipman, D. J. 1990. Basic local alignment search tool. J. Mol. Biol. 215:403-410.

3. Atreya, P. L., Atreya, C. D., and Pirone, T. P. 1991. Amino acid substitutions in the coat protein result in loss of insect transmissibility of a plant virus. Proc. Natl. Acad. Sci. USA 88:7887-7891.

4. Badge, J., Robinson, D. J., and Brunt, A. A. 1997. 3'-Terminal sequences of the RNA genomes of narcissus latent and maclura mosaic viruses suggest that they represent a new genus of the Potyviridae. J. Gen. Virol. 78:253-257.

5. Bellardi, M. G., Bertaccini, A., and Marani, F. 1988. A PVY isolate infecting Ranunculus. Phytopathol. Mediterr. 27:157-162.

6. Clark, M. F., and Adams, A. N. 1977. Characteristic of the microplate method of enzyme-linked immunosorbent assay for the detection of plant viruses. J. Gen. Virol. 34:475-483.

7. Devereux, J., Haeerli, P., and Smithies, O. 1984. A comprehensive set of sequence analysis programs for the VAX. Nucleic Acids Res. 12:387-395.

8. Devergne, J. C., Cardin, L., and Marais, A. 1969. Isolement de quelques virus infectant le Renoncule cultivee, Ranunculus asiaticus L., dans le sud-est de la France. Ann. Phytopathol. 1:321-328.

9. Elliott, M. S., Zettler, F. W., Gallegati, M., and Ko, N. J. 1988. A potyvirus infecting Ranunculus asiaticus. Acta Hortic. 234:39.

10. Felsenstein, J. 1989. PHYLIP-phylogeny inference package (version 3.2). Cladistics 5:164-166.

11. Fukumoto, F., and Tochihara, H. 1978. Chinese yam necrotic mosaic virus. Ann. Phytopathol. Soc. Jpn. 44:1-5.

12. Gonsalves, D., Trujillo, E., and Hoch, H. C. 1986. Purification and some properties of a virus associated with cardamom mosaic, a new member of the potyvirus group. Plant Dis. 70:65.

13. Heinze, C., Roggero, P., Sohn, M., Vaira, A.-M., Masenga, V., and Adam, G. 2000. Peptide-derived broad-reacting antisera against tospovirus NSsprotein. J. Virol. Methods 89:137-146.

14. Hollings, M. 1957. Anemone mosaic-A virus disease. Ann. Appl. Biol. 45:44-61.

15. Laird, E. F., and Dickson, R. C. 1965. Certain biological properties of a virus from Ranunculus asiaticus. Plant Dis. Rep. 49:449.

16. Laird, E. F., and Dickson, R. C. 1967. Ranunculus mottle virus: Field incidence and insect vector relationships at Ponto, California. J. Econ. Entomol. 60:10-13.

17. Liou, R. F., Yan, H. Z., and Hong, J. L. 2003. Molecular evidence that aphid-transmitted Alpinia mosaic virus is a tentative member of the genus Macluravirus. Arch. Virol. 148:1211-1218.

18. Meynet, J. 1993. Ranunculus. Pages 603-610 in: The Physiology of Flower Bulbs. A. De Hertogh and M. Le Nard, eds. Elsevier Science, The Netherlands.

19. Ohshima, K., Yamaguchi, Y., Hirota, R., Hamamoto, T., Tomimura, K., Tan, Z., Sano, R., Azuhata, F., Walsh, J. A., Fletcher, J., Chen, J., Gera, A., and Gibbs, A. 2002. Molecular evolution of Turnip mosaic virus: Evidence of host adaptation, genetic recombination and geographical spread.
J. Gen. Virol. 83:1511-1521.

20. Padma, R., Singh, S., and Verma, V. S. 1972. Studies on a virus disease of buttercup. Z. Pflanzenkrankh. Pflanzen. 79:710-713.

21. Raabe, R. D., and Gold, A. H. 1957. A virus that causes mosaic of Ranunculus (Ranunculus asiaticus L.). Phytopathology 47:28.

22. Ragozzino, A. 1972. Due malattie da virus del ranuncolo in Campania. Riv. Ortoflorofut. Ital. 56:157-161.

23. Roggero, P., Masenga, V., and Tavella, L. 2002. Field isolates of Tomato spotted wilt virus overcoming resistance in pepper and their spread to other hosts in Italy. Plant Dis. 86:950-954.

24. Sangers, F., Nicken, S., and Coulson, A. R. 1977. DNA sequencing with chain-terminating inhibitors. Proc. Natl. Acad. Sci. USA 74:5463-5467.

25. Shagger, H., and von Jagow, G. 1987. Tricine-sodium dodecyl sulfatepolyacrylamide gel electrophoresis for the separation of protein in the range from 1 to $100 \mathrm{kDa}$. Anal. Biochem. 166:368-379.

26. Shukla, D. D., and Ward, C. W. 1988. Amino acid sequence homology of coat proteins as a basis for identification and classification of the potyvirus group. J. Gen. Virol. 69:2703.

27. Thompson, J. D., Higgins, D. G., and Gibson, T. J. 1994. CLUSTAL W: Improving the sensitivity of progressive multiple sequence alignment through sequence weighting, position-specific gap penalties and weight matrix choice. Nucleic Acids Res. 22:4673-4680.

28. Turina, M., Desvoyes, B., and Scholthof, K.-B. G. 2000. A gene cluster encoded by panicum mosaic virus is associated with virus movement. Virology 266:120-128.

29. Turina, M., Maruoke, M., Monis, J., Jackson, A. O., and Scholthof, K.-B. G. 1998. Nucleotide sequence and infectivity of a full-length cDNA clone of Panicum mosaic virus. Virology 241:141-155.

30. Urcuqui-Inchima, S., Haenni, A., and Bernardi, F. 2000. Potyvirus proteins: A wealth of functions. Virus Res. 74:157-175.

31. Vaira, A. M., Lisa, V., and Dellavalle, G. 1992. Distribution of tospovirus in Liguria, Italy. Pages 23-24 (Abstr.) in: Viruses, Vectors and the Environment. 5th Int. Plant Virus Epidemiology Symposium. CIHEAM Instituto Agronomico Mediterraneo Ed., Valenzano, Bari.

32. Vaira, A. M., Milne, R. G., Accotto, G. P., Luisoni, E., Masenga, V., and Lisa, V. 1997. Partial characterization of a new virus from ranunculus with a divided RNA genome and circular supercoiled thread-like particles. Arch. Virol. 142:2131-2146.

33. Vance, V. B. 1991. Replication of Potato virus X RNA is altered in coinfection with Potato virus Y. Virology 182:486-494.

34. Van Regenmortel, M. H. V., Fauquet, C. M., Bishop, D. H. L., Carstens, E. B., Estes, M. K., Lemon, S. M., Maniloff, J., Mayo, M. A., McGeoch, D. J., Pringle, C. R., and Wickner, R. B. (eds.) 2000. Virus Taxonomy. Seventh Report of the International Committee on Taxonomy of Viruses. Academic Press, New York.

35. Whitfield, A. E., Campbell, L. R., Sherwood, J. L., and Ulmann, D. E. 2003. Tissue blot immunoassay for detection of Tomato spotted wilt virus in Ranunculus asiaticus and other ornamentals. Plant Dis. 87:618622.

36. Wylie, S. J., Kueh, J., Welsh, B., Smith, L. J., Jones, M. G. K., and Jones, R. A. C. 2002. A non-aphid-transmissible isolate of bean yellow mosaic potyvirus has an altered NAG motif in its coat protein. Arch. Virol. 147:1813-1820. 